\title{
CARACTERÍSTICAS, FUNÇÕES E PRESERVAÇÃO DIGITAL DO ARCHIVEMATICA Ã LUZ DA RESOLUÇÃO Nº 43 DO CONSELHO NACIONAL DE ARQUIVOS
}

\author{
Wellington da Silva Gomes \\ Mestrado em Ciência da Informação - PPGCI - UFPB \\ wbless07@gmail.com
}

Marynice de M. M. Autran

Orientadora

Doutora em Informação e Comunicação em Plataformas Digitais

Professora do DCI e do PPGCI-UFPB

marynice.autran@gmail.com

\begin{abstract}
Resumo
A emergência das Tecnologias da Informação e Comunicação (TICs) fez surgir um novo paradigma na sociedade pós-industrial: o da evolução tecnológica sobre a informação. Isto acarretou a dinamização dos meios de comunicação instrumentalizados pela informática e Internet, especialmente, na difusão do que se conhece como o ciberespaço. Tais alterações tiverem impacto na realidade dos campos científicos que tem como práxis a relação entre análise e objeto: a informação, os quais passaram se adaptar às transformações causadas pelo progresso tecnológico, produzindo mecanismos para racionalizar e controlar o aumento dos seus registros. Destarte, a transição dos documentos analógicos para os digitais, prova inconteste que as (TICs) vêm possibilitando diferentes formas de interação entre os indivíduos, tem alterado a forma de pensar o gerenciamento da informação no ambiente virtual, sobretudo, pela intermediação do hardware e software. Dessa forma, percebe-se, que os softwares livres possuem papel essencial no gerenciamento informacional. Esta pesquisa teve como objetivo geral: Analisar o Archivematica a partir das perspectivas arquivísticas dos requisitos da Resolução $\mathrm{n}^{\circ} 43$ do CONARQ e como objetivos específicos: Analisar as funcionalidades e características do Archivematica de acordo com o Guia do usuário e sua página eletrônica; Caracterizar o referido sistema e Verificar se suas funções preenchem os requisitos preconizados pela Resolução $n^{0} 43$. Trata-se de uma pesquisa com caráter descritivo, bibliográfico e documental com abordagem qualitativa e utilização do método comparativo. Os resultado demonstram o total cumprimento dos requisitos preconizados pela Resolução 43, o que respalda o Archivematica como um repositório digital arquivístico confiável.
\end{abstract}

Palavras-chave: Archivematica. Repositório Digital Arquivístico Confiável (RDC-Arq). Software livre. 